\title{
Effect of adsorbent and phospholipide on meat production and nutritional value of fattened calf bull meat
}

\author{
Maksim Shabanov ${ }^{1, *}$, Victor Temiraev ${ }^{1}$, Taladin $\mathrm{Kokov}^{2}$, Beslan Efendiev ${ }^{2}$, and Shamurat \\ Herremov $^{3}$ \\ ${ }^{1}$ Federal State Budgetary Educational Institution of Higher Education Gorsky State Agrarian \\ University, Kirova Str., 37, 362040 Vladikavkaz, Russia \\ ${ }^{2}$ Kabardino-Balkarian State Agricultural University named after V.M. Kokov, Lenin Avenue, 1V, \\ 360030 Nalchik, Russia \\ ${ }^{3}$ Union of Industrialists and Entrepreneurs of Turkmenistan, Atamurad Niyazova Av., 174, 744000 \\ Ashgabat, Turkmenistan
}

\begin{abstract}
One of the most effective ways of removing HM salts that have entered the digestive tract of fattened animals is the technological method of including adsorbent preparations in their diets, which, binding various toxins, excrete them from the body. The study purpose is to develop a method to increase the meat productivity and quality of meat of young cattle for fattening in a technogenic zone by inclusion of ToxySorb adsorbent in their diets with a high content of heavy metal salts in the amount of $1.25 \mathrm{~kg} / \mathrm{t}$ of compound feed and lecithin in the amount of 10 $\mathrm{g} / 100 \mathrm{~kg}$ of live weight. According to study results, it was shown that when these drugs were fed together in the indicated quantities, it contributed to better detoxification of xenobiotics. The calf bulls of experimental group 3 had the best slaughter indicators, as well as the best consumer, sanitary and hygienic properties of meat products.
\end{abstract}

\section{Introduction}

At present, beef production is increased to satisfy the Russian consumer needs with complete protein of animal origin. At the same time, a greater share in beef production in our country is occupied by meat as a result of young livestock fattening, primarily dairy and mixed breed calf bulls. At the same time, the duration of calf bull fattening is one year, starting from six months of age, until they reach a body weight of more than $400 \mathrm{~kg}$. If these requirements are met, with good nutrition of fattened animals, an optimal ratio of proteins, lipids, mineral and biologically active substances is observed in beef $[1,2,3]$.

Considering such requirements, with the rational organization of beef production by calf bull fattening, successful implementation of genetically determined potential of their body, first of all, helps to ensure physiological body needs for energy and all necessary nutrients. However, this problem cannot be solved only by a full-fledged balanced feeding

\footnotetext{
* Corresponding author: kapmar17@gmail.com
} 
of young fattening cattle according to current rations. The effective fattening of calf bulls is supported by the use of high-quality feed in the diet. Moreover, in modern conditions, with this approach to feeding calf bulls for meat, close attention is paid to ecological safety of feed $[4,5]$.

In recent decades, anthropogenic loads on the environment have increased due to intensive development of industrial enterprises, transport, construction, chemicalization of agriculture, etc. It results in the contamination of soil, plants, plant and animal origin food with various chemical toxicants. One of the most dangerous toxicants for the human and animal body are heavy metal (HM) salts. They gradually accumulate in organs and tissues (they are not excreted) and subject the body to intoxication in growing dynamics $[6,7,8]$.

It is known that the North Ossetia Republic territory, due to the presence of a number of large enterprises of non-ferrous metallurgy and vehicles, is characterized by a high level of soil pollution and plant feed crops with heavy metal salts (first of all, such elements as copper, lead, zinc, cadmium, etc.). Therefore, the development of methods to prevent contamination with these compounds of meat products produced in the technogenic zone of the Republic of North Ossetia-Alania is constantly underway [9, 10, 11]

One of the most effective ways of removing HM salts that have entered the digestive tract of fattened animals is the technological method of including adsorbent preparations in their diets, which, binding various toxins, excrete them from the body. There is good experience in the synergistic effect of adsorbents with other biologically active additives (BAA), including phospholipids, for elimination of these toxins [12, 13, 14].

As a result, our purpose was to develop a method to increase the meat productivity and quality of fattening calf bulls in a technogenic zone by including ToxySorb adsorbent and phospholipid lecithin in their diets with a high content of HM salts.

\section{Materials and Methods}

We studied Schwyz calf bulls in the Republic of North Ossetia-Alania. Of these, at the age of six months, according to the principle of analogous pairs, we formed four groups of ten animals each. They were fed during fattening (lasting 12 months) with balanced diets according to the scheme shown in Table 1 .

The tested feed additives in the compound feed shop were introduced into the compound feed for experimental animals with the help of industrial dispensers and mixed.

Upon reaching the age of 18 months, 3 calf bulls, typical in body weight and fatness, were selected from each group, they were slaughtered according to the generally accepted procedure.

In selected average samples of the rib eye muscle of calf bulls from compared groups, the chemical composition, biological value and ecological safety of meat were studied using conventional methods.

Table 1. Substantiation of schematic diagrams for introduction of preparations into the diets of calf bulls, $\mathrm{n}=10$.

\begin{tabular}{|l|l|}
\hline \multicolumn{1}{|c|}{ Group } & \multicolumn{1}{c|}{ Feeding features } \\
\hline Control & Basic diet (BD) with excessive levels of $\mathrm{Zn}, \mathrm{Cd}, \mathrm{Pb}$ salts \\
\hline Experimental 1 & $\begin{array}{l}\mathrm{BD}+\text { ToxySorb adsorbent in the amount of } 1.25 \mathrm{~g} / \mathrm{t} \\
\text { compound feed }\end{array}$ \\
\hline Experimental 2 & $\begin{array}{l}\text { BD + lecithin preparation in the amount of } 10 \mathrm{~g} / 100 \mathrm{~kg} \text { of } \\
\text { live weight }\end{array}$ \\
\hline Experimental 3 & $\begin{array}{l}\text { BD + ToxySorb adsorbent in the amount of } 1.25 \mathrm{~kg} / \mathrm{t} \text { of } \\
\text { compound feed + lecithin preparation in the amount of } 10 \\
\mathrm{~g} / 100 \mathrm{~kg} \text { of live weight }\end{array}$ \\
\hline
\end{tabular}


All the obtained digital material on a personal computer was biometrically processed with the establishment of the Student's test of validity.

\section{Results and Discussion}

During the experiment, the concentration of these toxicants in the diet for the experimental calf bulls was regularly studied. It was determined that fattening animals in winter diet had an excess of maximum permissible concentrations (MPC) for $\mathrm{Pb}$ (lead) by $63.1-64.3 \%, \mathrm{Zn}$ (zinc) - by 67.0-67.3\%, and Cd (cadmium) - by 62.6-63.0\%, in summer diet - by 61.2$61.4 \%$; 66.1-66.4 and 60.3-60.6\%, respectively.

During the slaughter, we studied the effect of the feed preparations on the slaughter indicators of the fattened calf bulls, shown in Fig. 1.

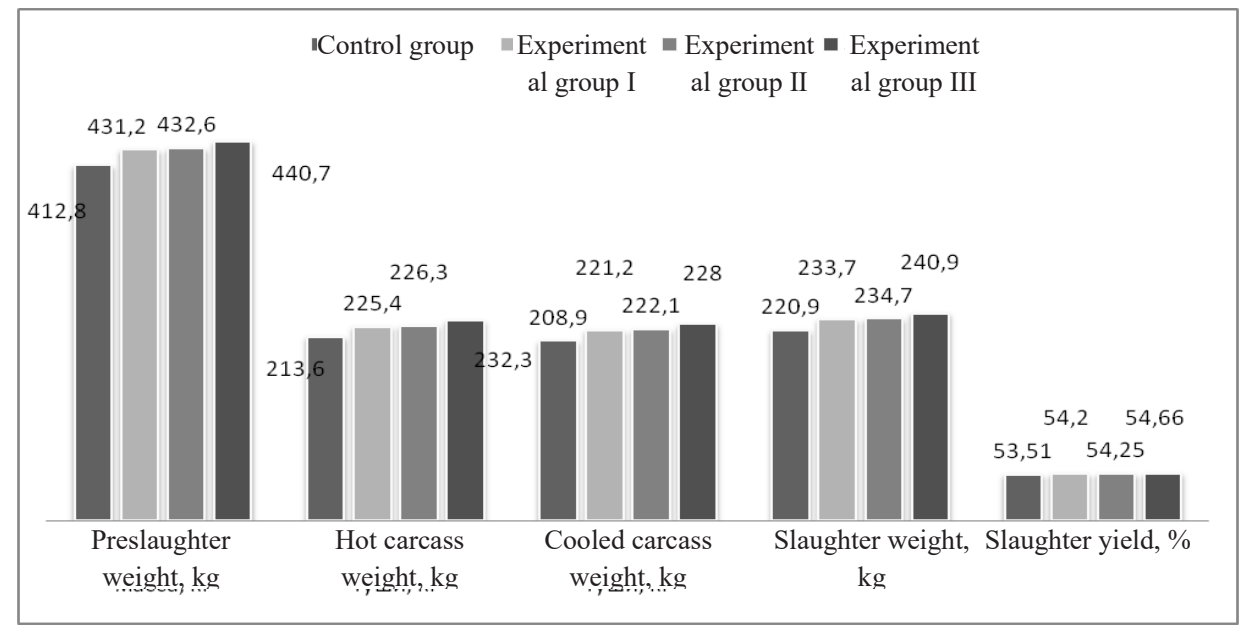

Fig. 1. Effect of tested preparations on slaughter indicators of calf bulls.

It was determined that joint additions of adsorbent and phospholipid complex to compound feed had a more favorable effect on slaughter indicators in experimental fattening of young cattle. As a result, in comparison with the control group, animals of experimental group 3 had higher parameters characterizing their pre-slaughter weight by $6.76 \%(\mathrm{P}<0.05)$, slaughter weight - by $9.05 \%(\mathrm{P}<0.05)$, hot carcass weight - by $8.75 \%(\mathrm{P}$ $<0.05)$, chilled carcass weight - by $9.14 \%(\mathrm{P}<0.05)$ slaughter yield - by $1.15 \%(\mathrm{P}<0.05)$. It is considered as a consequence of the best detoxification effect, thanks to the rational intake of ToxySorb adsorbent for feeding, showing synergistic effect for removal of HM salts from the body with lecithin, helped to optimize the slaughter indicators of fattened animals.

The nutritional value of calf bull meat of compared groups is more clearly characterized by the chemical composition of eye rib samples, their indicators are shown in Fig. 2. 


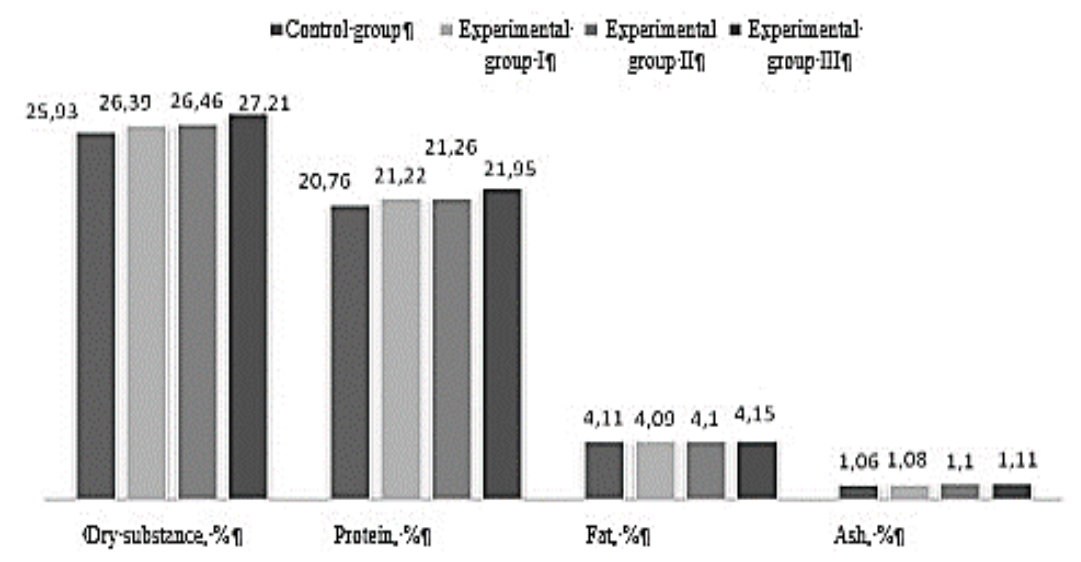

Fig. 2. Effect of tested preparations on the chemical composition of calf bull meat.

Analysis of the chemical composition of the eye rib samples showed that the joint feeding of the tested preparations contributed to the improvement of the nutritional value of the produced beef. This versus animals of the control group was manifested in an increase in the meat samples of analogs from experimental group 3 of indicators of dry matter concentration by $1.28 \%(\mathrm{P}<0.05)$ and protein - by $1.19 \%(\mathrm{P}<0.05)$.

An equally important indicator for evaluation of meat nutritional quality is the determination of its biological value, taking into account tryptophan and hydroxyproline levels (Fig. 3), determined for the animals of compared groups by calculating the proteinquality indicator (PQI) (Fig. 4).

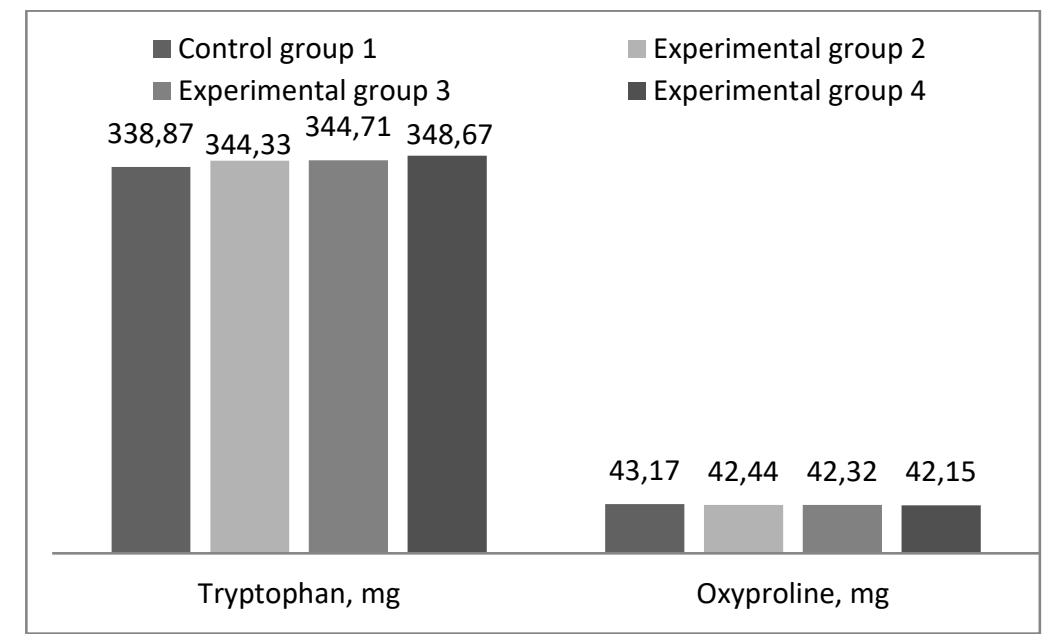

Fig. 3. Concentration of tryptophan and hydroxyproline in calf bull meat. 


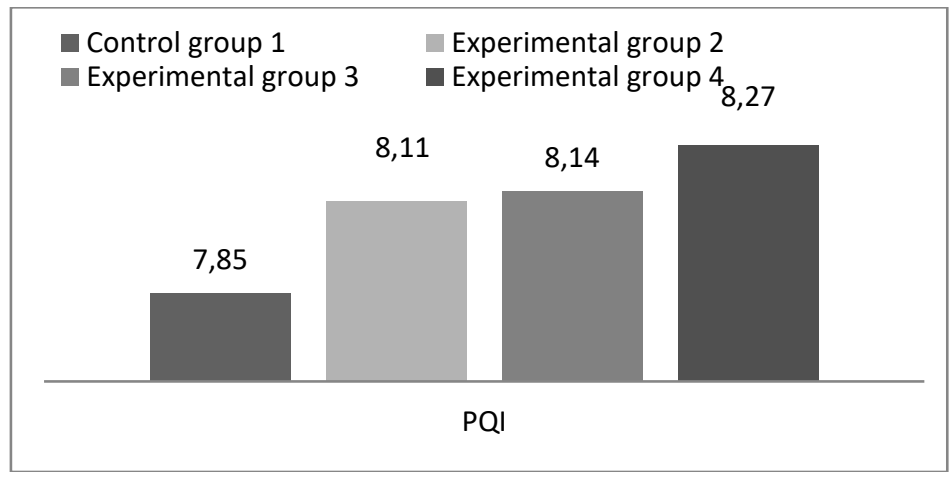

Fig. 4. Protein-quality indicator of calf bull meat.

It was determined that due to combined adsorbent and lecithin preparation feeding, it was possible to achieve a significant $(\mathrm{P}<0.05)$ increase in the concentration of the essential amino acid tryptophan by $2.89 \%$ in the bulls of experimental group 3 in rib eye samples versus control group. Thanks to this, it became possible to increase the biological value of meat samples from animals of experimental group 3, which also surpassed their control equivalents in terms of PQI by $5.4 \%$. It demonstrates protein metabolism improvement in animals of experimental group 3 due to better elimination of toxicants.

It is confirmed by the content of zinc salts (Fig. 5), lead (Fig. 6) and cadmium (Fig. 7) in calf bull meat samples from compared groups.

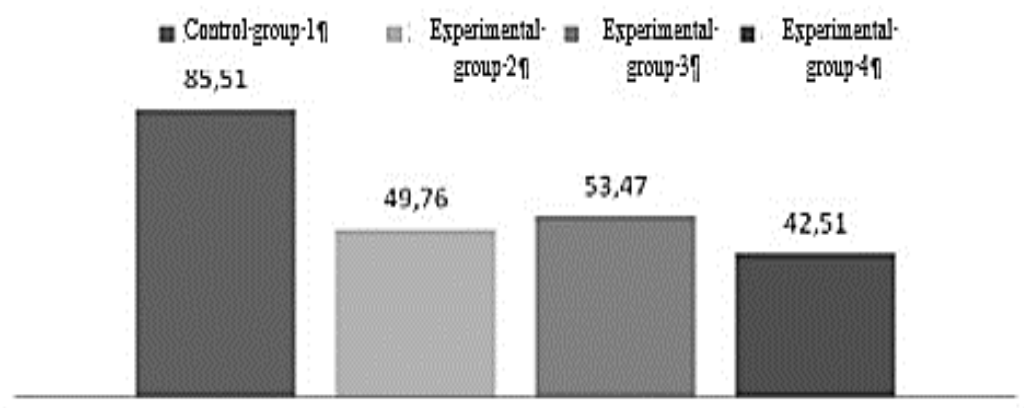

\section{Zimc(MAC $=70$ mog $/ \mathrm{kg}) \ln$}

Fig. 5. Zinc content in meat samples of calf bulls from compared groups.

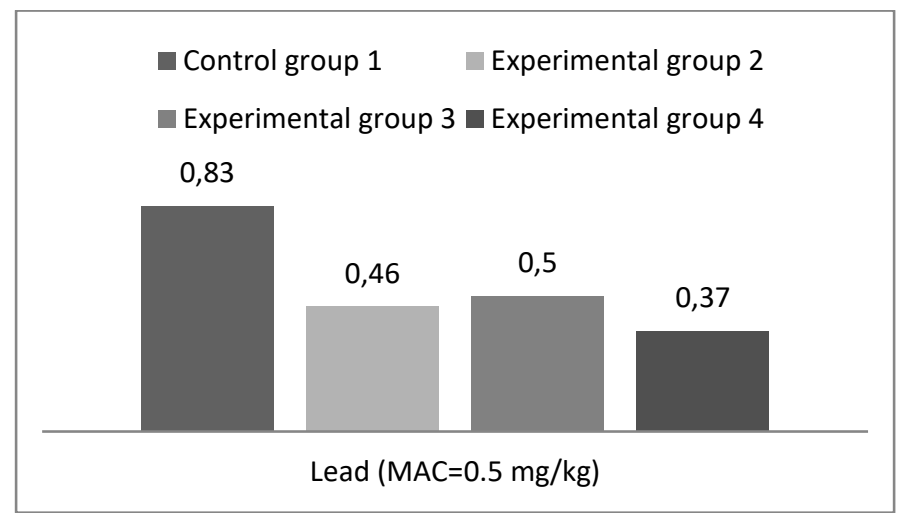

Fig. 6. Lead content in meat samples of calf bulls from compared groups. 


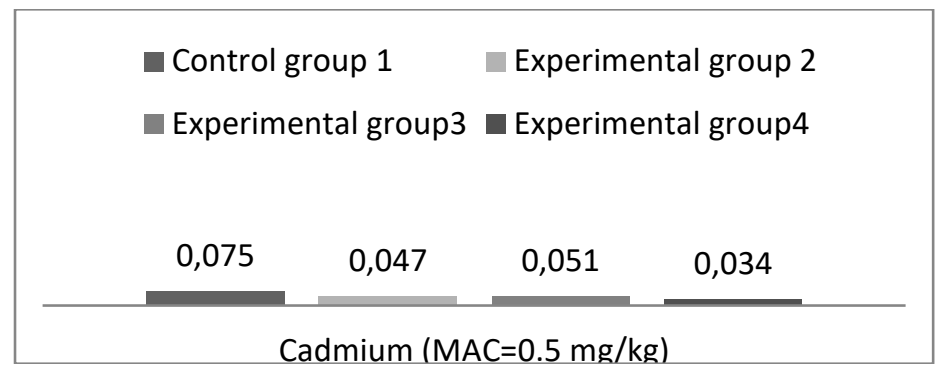

Fig. 7. Cadmium content in meat samples of calf bulls from compared groups.

It was determined that the joint feeding of adsorbent and lecithin preparations had a more favorable effect on the ecological safety of produced beef during the experiment. It was manifested relative to control group equivalents in a decrease in the eye rib samples of animals of experimental group 3 in the concentration of zinc by 2.01 times $(\mathrm{P}<0.05)$, lead - by $2.24(\mathrm{P}<0.05)$ and cadmium - 2.21 times $(\mathrm{P}<0.05)$. It should be noted that in the calf bull meat samples of experimental group 3, there was no excess of MPC for any of these elements.

\section{Conclusions}

An effective method to increase the meat productivity and nutritional quality of calf bull meat in the technogenic zone of North Ossetia-Alania is the joint feeding of ToxySorb adsorbent in the diet with an increased level of heavy metal (HM) salts in the amount of $1.25 \mathrm{~kg} / \mathrm{t}$ of compound feed and lecithin in the amount of $10 \mathrm{~g} / 100 \mathrm{~kg}$ of live weight.

\section{References}

1. Y. A. Yuldashbaev, R. B. Temiraev, V. V. Tedtova, et al., J. of Livestock Science, 11, 8-13 (2020)

2. S. I. Kononenko, R. B. Temiraev, A. A. Gazdarov, Modern problems of dairy and beef cattle breeding, milk and beef production: Proceedings of International scientific and practical conference, 181-183 (2012)

3. R. B. Temiraev, Z. T. Baeva, A. V. Muzaeva, N. G. Ter-Teryan, I. A. Arishina, Proceedings of the Kuban State Agrarian University, 21, 140-143 (2009)

4. V. V. Tedtova, Z. T. Baeva, E. S. Dzodzieva, Z. Ya. Tsopanova, A. Kh. Pilov, Meat Industry, 3, 60-62 (2013)

5. V. K. Temiraev, V. R. Kairov, R. B. Temiraev, Z. A. Kubatieva and V. M. Gukezhev, Ecology, Environment and Conservation, 23(1), 554-561 (2017)

6. B. Temiraev, L. V. Tsalieva, I. G. Plieva, M. R. Dzutseva, Bulletin of the Gorsky State Agrarian University, 47(2), 85-87 (2010)

7. R. B. Temiraev, Z. T. Baeva, U. I. Teziev, A. A. Gazdarov, Dairy Industry, 5, 73-74 (2009)

8. E. S. Dzodzieva, M. G. Kokaeva, R. B. Temiraev, G. A. Abramova, D. O. Gurtsieva, Meat Industry, 2, 46-48 (2015)

9. V. K. Temiraev, V. R. Kairov, R. V. Kalagova, Biology and Medicine, 6(3), BM-04614 (2014) 
10. L. V. Tsalieva, R. B. Temiraev, S. I. Kononenko, B. A. Dzagurov, M. S. Gazzaeva and S. A. Grevtsova, J. of Pharmaceutical Sciences and Research, 9(12), 2397-2400 (2017)

11. S. Kononenko, R. Temiraev, Z. Baeva, A. Gazdarov, Kombikorma (Compound Feed), 6, 104-105 (2011)

12. V. A. Pogodaev, A. N. Arilov, A. F. Shevhuzhev, A. P. Marynich, R. Kh. Kochkarov, Research J. of Pharmaceutical, Biological and Chemical Sciences, RJPBCS, 8(1), 1086-1090 (2017)

13. V. A. Pogodaev, A. P. Marynich, S. V. Frolko, E. G. Mishvelov, and A. Y. Glushko, Research J. of Pharmaceutical, Biological and Chemical Sciences, RJPBC, 7(4), 13451348 (2016)

14. R. B. Temiraev, M. K. Kozhokov, S. K. Cherchesova, F. F. Kokaeva, I. R. Tletseruk, J. of Environmental Management and Tourism, 3(19), 567-573 (2017) 